
\title{
25 Research Square \\ Effects of Drainage on Greenhouse Gas Emissions and Yields of Lowland Rice-Wheat Rotation System in East China
}

\section{$\mathrm{HaO} \mathrm{He}$}

Anhui Agricultural University

Dandan Li

Anhui Agricultural University

Ze Wu

Anhui Agricultural University

Tiancheng Zhang

Anhui Agricultural University

Feifan Pan

Anhui Agricultural University

\section{Fengwen Wang}

Anhui Agricultural University

\section{Shuyun Yang ( $\square$ yangshy@ahau.edu.cn )}

Anhui Agricultural University

\section{Youhua Ma}

Anhui Agricultural University

\section{Research Article}

Keywords: Drainage, Rice-wheat rotation, CH4, N2O, GWP, GHGI

Posted Date: December 28th, 2021

DOI: https://doi.org/10.21203/rs.3.rs-1110676/v1

License: @ (i) This work is licensed under a Creative Commons Attribution 4.0 International License. Read Full License 


\section{Abstract}

The subtropical region of East China is characterized by abundant water and temperature resources conducive to crop cultivation, and large areas of lowland have been widely used for agricultural planting. To explore the feasible methods of greenhouse gases (GHGs) reduction for rice-wheat rotation system, shallow ditch (SD) and deep ditch (DD) treatments in the wheat season were set up for drainage to control the water content in soil, with the conventional non-ditching treatment as the control group (CG). Results showed that methane $\left(\mathrm{CH}_{4}\right)$ emissions from paddy soil were in the majority in global warming potential (GWP) in rice-wheat rotation system. In the three years, compared with that of $\mathrm{CG}$, the $\mathrm{CH}_{4}$ cumulative emissions of SD and DD were reduced by $65.80 \%$ and $63.42 \%$ (rice season), and $101.37 \%$ and $77.28 \%$ (wheat season), respectively; the nitrous oxide $\left(\mathrm{N}_{2} \mathrm{O}\right)$ cumulative emissions of SD and DD were reduced by $27.62 \%$ and $11.30 \%$ (rice season), and $1.53 \%$ and $-37.40 \%$ (wheat season), respectively; the total GWP produced by SD and DD in the three years was reduced by $58.78 \%$ and $52.22 \%$, respectively; GHG emission intensity (GHGI) of SD and DD declined by $60.67 \%$ and $53.85 \%$, respectively; the $\mathrm{CH}_{4}$ emission flux was significantly positively correlated with atmospheric temperature and $5 \mathrm{~cm}$ ground temperature, but negatively correlated with soil Eh; when the soil Eh value was lower than $-150 \mathrm{mV}$, the $\mathrm{CH}_{4}$ emission flux increased significantly, indicating that -150 mV was the key soil Eh value for $\mathrm{CH}_{4}$ emissions in this area; in addition, both SD and DD led to markedly decrease in soil organic matter content and an increase in soil $\mathrm{pH}$. The findings indicate that SD and DD not only ensure stably increasing production, but also effectively reduce GHG emissions.

\section{Introduction}

Methane $\left(\mathrm{CH}_{4}\right)$ and nitrous oxide $\left(\mathrm{N}_{2} \mathrm{O}\right)$ are important greenhouse gases (GHGs), which contribute over $20 \%$ to the global increase in radiative forcing (Banger et al. 2012; Huang et al. 2018). Agricultural production has been recognized one of the dominant sources of $\mathrm{CH}_{4}$ and $\mathrm{N}_{2} \mathrm{O}$ emissions (Cheng et al. 2021; Wang et al. 2020), the characteristics of high humidity and high organic carbon of the paddy field soil determine that the paddy soil is the main source of $\mathrm{CH}_{4}$ emissions (Haque and Biswas 2021; Pratibha et al. 2016). The annual total emissions of $\mathrm{CH}_{4}$ in the global paddy fields account for approximately $5-19 \%$ of the total, while $\mathrm{N}_{2} \mathrm{O}$ contributes up to $6-10 \%$ in global warming (Saarenheimo et al. 2015).

Rice-wheat rotation is a common planting system in East Asia and Southeast Asia. Winter wheat is planted during the slack winter season, so that the maximum benefits of winter farmland can be fully utilized through crop rotation. The areas of farmland under the rice-wheat rotation pattern account for more than half of the total rice areas in China (Zhao et al. 2009). This pattern includes irrigated paddy fields and dryland wheat fields, so it is difficult to count the GHG emissions in the entire rotation system (Montoya-González et al. 2009; Tellez-Rio et al. 2015). The yield of rice and wheat in eastern China contributes nearly $30 \%$ to China's grain production, making an important contribution to ensuring the safety of food production. With available water and temperature resources conducive to crop cultivation, rice-wheat rotation is an important planting system in fields along the middle and lower reaches of the Yangtze River among the main grain-producing areas in China (Hou et al. 2016; Xu et al. 2009), which to a certain extent also represents the watershed of China's humid and semi-humid regions. Chao Lake area is a typical polder area with a rice-wheat rotation pattern. A polder area refers to the low-lying drainage area formed by an embankment network of plain rivers and lakes along the rivers, which is comprised of a lower terrain, a shallow soil tillage layer, and high groundwater level. Large polder areas have been widely used for 
agricultural planting, whose distribution is related to rivers and lakesides (Nillesen and Kok 2015). In the context of increasing demand for grain production, it is of great global significance to mitigate and adapt to climate change for researching and promoting the reduction of GHGs in rice-wheat rotation system.

$\mathrm{CH}_{4}$ is an organic gas produced by methanogens decomposing organic matter in an extremely anaerobic environment. For the paddy fields, soil water control is a highly important factor affecting $\mathrm{CH}_{4}$ and $\mathrm{N}_{2} \mathrm{O}$ emissions, and the influences of water managements such as draining and alternate wetting and drying (AWD) on the $\mathrm{CH}_{4}$ and $\mathrm{N}_{2} \mathrm{O}$ emissions in farmlands have been well documented (Liang et al. 2017; Liang et al. 2016; Schimel et al. 2011). Related research has shown that the higher soil water content in winter will make the soil remain an extremely anaerobic state, thus promoting the emissions of $\mathrm{CH}_{4}$ (Wu et al. 2018; Xu et al. 2003; Zhao et al. 2020). According to Kang et al. (2002) and Jain et al. (2014), water control in non-rice growing period is effective in controlling $\mathrm{CH}_{4}$ emissions in China's rice growing period. Related scholars reported that drainage helps reduce $\mathrm{CH}_{4}$ emissions by destroying the extreme anaerobic environment of methanogens, while flooded paddy soils are global sources of $\mathrm{CH}_{4}$ due to the lack of oxygen (David et al. 2018; Liang et al. 2016). $\mathrm{N}_{2} \mathrm{O}$ emissions from continuously flooded paddy fields are very low, and they are often ignored (Johnson-Beebout et al. 2009). However, water managements on farmlands usually produce large amount of $\mathrm{N}_{2} \mathrm{O}$ emissions. Linquist et al. (2012) showed that the drainage in the wheat season leads to an increase in $\mathrm{N}_{2} \mathrm{O}$ emissions from rice fields and a significant decrease in $\mathrm{CH}_{4}$ emissions. Liu et al. (2019) showed through meta-analysis that draining in paddy fields is an effective way to mitigate GHG emissions in rice ecosystem, the global warming potential (GWP) of $\mathrm{CH}_{4}$ and $\mathrm{N}_{2} \mathrm{O}$ under mid-season drainage decreases significantly compared with that under continuous flooding. Furthermore, Hou et al. (2016) reported that water management has a significant impact on GHG emissions from rice-wheat rotation system, and long-term flooded rice fields have lower $\mathrm{N}_{2} \mathrm{O}$ emissions. Another report pointed out that if a water control method is used in the flooded farmland in southwest China in winter, the total $\mathrm{CH}_{4}$ emissions during the growth period of the next rice season will be effectively reduced by approximately $63-72 \%$ (Cai et al. 1998). Water control measures can inhibit $\mathrm{CH}_{4}$ emissions, but it may increase $\mathrm{N}_{2} \mathrm{O}$ emissions at the same time (Cai et al. 2000). However, it remains unclear whether the corresponding increase in $\mathrm{N}_{2} \mathrm{O}$ emissions can partially offset or overcompensate the positive impact on $\mathrm{CH}_{4}$ mitigation, leading to an increase or decrease in GWP (Khalid et al. 2019). Moreover, most studies on the impact of water management on $\mathrm{N}_{2} \mathrm{O}$ and $\mathrm{CH}_{4}$ emissions are restricted to the rice season. Relatively few studies have been devoted to the effects of water control during the wheat season on the GHG emissions of the entire annual rice-wheat rotation (Hou et al. 2016).

In order to explore a feasible plan for reducing GWP under the rice-wheat rotation pattern, a three-year experiment was conducted, with the rice-wheat two-cropping farmland of Chao Lake polder area as the research object. Two water control treatments easy to be implemented and a control treatment were designed. In addition, the influencing factors for $\mathrm{CH}_{4}$ emissions from paddy soils were analyzed, such as atmospheric temperature, $5 \mathrm{~cm}$ ground temperature and soil Eh. The results are applicable to the emission reduction and efficiency enhancement technology of subtropical rice-wheat rotation farmland cultivation in China.

\section{Materials And Methods \\ 2.1. Experiment site}


The experiment was conducted at the Chao Lake Agricultural Environment Experimental Station of Anhui Agricultural University from 2013 to 2015. The monitoring site was located in Tangzui Village, Qi Town, Chaohu City $\left(117^{\circ} 41^{\prime} 6 " \mathrm{E}\right.$ and $31^{\circ} 39^{\prime} 50^{\prime \prime} \mathrm{N}$ with an elevation of $\left.17 \mathrm{~m}\right)$, which belongs to the north subtropical monsoon climate zone. The annual average precipitation here is $1358.3 \mathrm{~mm}$, the average temperature is $16.8^{\circ} \mathrm{C}$, the annual frost-free period is 247 days, and the sunshine hours are $2106 \mathrm{~h}$. According to the statistics in 2014, the grain crop planting area was around 49,800 ha in Chaohu City, with a total output of approximately 319,000 tons of crop, and rice production of about 256,000 tons.

This field was managed according to the traditional practices in the area, wherein the rice was flooded during the growing season, and the uncultivated fields were left after harvest until the next cultivation. The rice and winter wheat varieties used for the experiment were Huiliangyou 996 and Yangmai 16.

The soil type of this monitoring site in the Chao Lake lowland area is submerged paddy soil with a pH value $\left(\mathrm{H}_{2} \mathrm{O}\right)$ of 6.19 , organic carbon content of $23.71 \mathrm{~g} \mathrm{~kg}^{-1}$, total nitrogen content of $1.29 \mathrm{~g} \mathrm{~kg}^{-1}$, and physical clay content of $488 \mathrm{~g} \mathrm{~kg}^{-1}$. The physical and chemical properties under different treatments from $0 \mathrm{~cm}$ to $20 \mathrm{~cm}$ soil are also shown in Table 1.

Table 1

Physical and chemical properties of $0 \mathrm{~cm}$ to $20 \mathrm{~cm}$ soil in each treatment

\begin{tabular}{|lllllll|}
\hline Treatments & $\begin{array}{l}\text { Organic } \\
\text { matter }\end{array}$ & $\begin{array}{l}\text { Total } \\
\text { nitrogen }\end{array}$ & $\begin{array}{l}\text { Nitrate } \\
\text { nitrogen }\end{array}$ & $\begin{array}{l}\text { Ammonium } \\
\text { nitrogen }\end{array}$ & $\begin{array}{l}\text { Available } \\
\text { nitrogen }\end{array}$ & $\mathbf{p H}$ \\
\cline { 2 - 6 } & $\mathbf{( \mathbf { g ~ k g } ^ { - 1 } )}$ & $\mathbf{( \mathbf { g ~ k g } ^ { - 1 } )}$ & $\mathbf{( \mathbf { m g ~ k g } ^ { - 1 } )}$ & $\mathbf{( \mathbf { m g ~ k g } ^ { - 1 } )}$ & $\mathbf{( \mathbf { m g ~ k g } ^ { - 1 } )}$ & $\mathbf{( \mathbf { H } _ { 2 } \mathbf { 0 } )}$ \\
\hline CG & 22.38 & 1.29 & 9.62 & 0.71 & 81.58 & 6.24 \\
\hline SD & 22.97 & 1.27 & 8.05 & 3.19 & 81.22 & 6.21 \\
\hline DD & 22.46 & 1.33 & 4.97 & 1.55 & 82.63 & 6.18 \\
\hline
\end{tabular}

\subsection{Water control and fertilization measurements}

In order to lower the groundwater level, ditches were set up for drainage during the wheat season. Two treatments and a control treatment were designed for the wheat season: Shallow ditch (SD): The depths of field ditch, row ditch and the ditch besides the field were 20,25 , and $35 \mathrm{~cm}$, respectively. Deep ditch (DD): The depths of field ditch, row ditch and the ditch besides the field were 30,40 , and $45 \mathrm{~cm}$, respectively; control group (CG): no ditch (schematic diagram of the field ditches is shown in Fig. 1). Each treatment was performed with 3 replicates. The designed depth of the ditch was determined based on actual situations. A large ditch outside the farmland was approximately $60-80 \mathrm{~cm}$ deep. The interval between the field drains was $3 \mathrm{~m}$ while ditches were interconnected.

The bund used to separate the experimental plots was made of cement. Each plot had water inlets and drains, and the drains were connected one another. Local routine management was adopted for the field management of each treated plot. The wheat season land was plowed before planting, and its depth was around $15 \mathrm{~cm}$. Rice would be irrigated 4-5 times during the growth period and irrigated for 1-2 days before the three fertilizations, and the depth was approximately 6-7 cm at the end of the roasting field. Regular pest and disease control was performed during the growing period to ensure the normal growth state of the rice and wheat. 
$\mathrm{N}$ fertilizer, $\mathrm{P}$ fertilizer, and $\mathrm{K}$ fertilizer were urea, superphosphate, and potassium chloride, respectively. The specific fertilization scheme and fertilization amount are shown in Table 2. The managements of wheat and rice fields in the three years are shown in Tables 3 and 4.

Table 2

Fertilization measures in 2013-2015 (kg/hm²)

\begin{tabular}{|c|c|c|c|c|c|c|c|c|c|}
\hline \multirow{2}{*}{$\begin{array}{l}\text { Rice } \\
\text { season }\end{array}$} & \multicolumn{3}{|c|}{ Base fertilizer } & \multirow{2}{*}{$\begin{array}{l}\text { Tillering fertilizer } \\
\mathrm{N}\end{array}$} & \multicolumn{2}{|c|}{ Panicle fertilizer } & \multicolumn{3}{|c|}{ Total fertilizer } \\
\hline & $\mathrm{N}$ & $\mathrm{P}_{2} \mathrm{O}_{5}$ & $\mathrm{~K}_{2} \mathrm{O}$ & & $\mathrm{N}$ & $\mathrm{K}_{2} \mathrm{O}$ & $\mathrm{N}$ & $\mathrm{P}_{2} \mathrm{O}_{5}$ & $\mathrm{~K}_{2} \mathrm{O}$ \\
\hline & 67.5 & 67.5 & 67.5 & 67.5 & 45 & 0 & 180 & 67.5 & 67.5 \\
\hline \multirow{3}{*}{$\begin{array}{l}\text { Wheat } \\
\text { season }\end{array}$} & \multicolumn{3}{|c|}{ Base fertilizer } & Winter fertilizer & \multicolumn{2}{|c|}{ Striking root fertilizer } & \multicolumn{3}{|c|}{ Total fertilizer } \\
\hline & $\mathrm{N}$ & $\mathrm{P}_{2} \mathrm{O}_{5}$ & $\mathrm{~K}_{2} \mathrm{O}$ & $\mathrm{N}$ & $\mathrm{N}$ & $\mathrm{K}_{2} \mathrm{O}$ & $\mathrm{N}$ & $\mathrm{P}_{2} \mathrm{O}_{5}$ & $\mathrm{~K}_{2} \mathrm{O}$ \\
\hline & 72 & 72 & 72 & 69 & 69 & 0 & 210 & 72 & 72 \\
\hline
\end{tabular}

Table 3

Field managements in the wheat season in 2012-2015

\begin{tabular}{|lllll|}
\hline $\begin{array}{l}\text { Wheat } \\
\text { season }\end{array}$ & $\begin{array}{l}\text { Sowing, applying base } \\
\text { fertilizer }\end{array}$ & $\begin{array}{l}\text { Applying winter } \\
\text { fertilizer }\end{array}$ & $\begin{array}{l}\text { Applying striking root } \\
\text { fertilizer }\end{array}$ & Harvesting \\
\hline $2012-2013$ & 2012.10 .31 & 2013.1 .17 & 2013.3 .5 & 2013.6 .1 \\
\hline $2013-2014$ & 2013.10 .26 & 2014.1 .9 & 2014.3 .5 & 2014.5 .26 \\
\hline $2014-2015$ & 2014.11 .06 & 2015.1 .28 & 2015.3 .13 & 2015.6 .6 \\
\hline
\end{tabular}

Table 4

Field managements in the rice season in 2013-2015

\begin{tabular}{|lllllll|}
\hline $\begin{array}{l}\text { Rice } \\
\text { season }\end{array}$ & $\begin{array}{l}\text { Transplanting } \\
\text { seedlings, applying } \\
\text { basal fertilizer }\end{array}$ & $\begin{array}{l}\text { Applying } \\
\text { tiller } \\
\text { fertilizer }\end{array}$ & $\begin{array}{l}\text { Field } \\
\text { sunning }\end{array}$ & $\begin{array}{l}\text { Irrigation } \\
\text { and } \\
\text { rehydration }\end{array}$ & $\begin{array}{l}\text { Applying } \\
\text { Panicle } \\
\text { fertilizer }\end{array}$ & Harvesting \\
\hline $2012-$ & 2013.6 .13 & 2013.6 .28 & 2013.7 .11 & 2013.7 .20 & 2013.7 .27 & 2013.9 .27 \\
\hline 2013 & & 2014.7 .8 & 2014.7 .17 & 2014.7 .21 & 2014.8 .20 & 2014.10 .10 \\
\hline $\begin{array}{l}2013- \\
2014\end{array}$ & 2014.6 .21 & 2015.7 .18 & 2015.8 .6 & 2015.8 .8 & 2015.8 .20 & 2015.9 .17 \\
\hline $2014-$ & 2015.6 .19 & & & & & \\
\hline 2015 & & & & & & \\
\hline
\end{tabular}

\subsection{Collection and measurements of $\mathrm{N}_{2} \mathrm{O}$ and $\mathrm{CH}_{4}$ emissions}

In this experiment, closed static boxes were used to monitor the sampling of farmland GHG under the rice-wheat rotation pattern in the Chao Lake lowland area. The boxes were made of $5 \mathrm{~mm}$-thick transparent glass $(50 \times 50 \times$ $60 \mathrm{~cm}$ and $50 \times 50 \times 120 \mathrm{~cm}$ ). The former one had a top cover, whereas the latter did not have one. The box of the first specifications was used when the crop plant was less than $60 \mathrm{~cm}$ high. The two-layer box was used when the height of the crop plant exceeds $60 \mathrm{~cm}$. Water was injected during the sampling process to keep the box sealed. Conventional gas sampling was carried out every day from 9:00 AM to 12:00 PM four times per day at an interval 
of 10 minutes. $60 \mathrm{~mL}$ of gas was sampled each time. The data were recorded, and the Eh value of the soil was monitored.

The samples were taken in the wheat season once a week, and every 3 to 5 days in the rice season, which could be adjusted rationally according to weather conditions. In the periods of fertilization, topdressing, and roasting, the samples were taken every two days. The collected gas samples were measured for $\mathrm{CH}_{4}$ and $\mathrm{N}_{2} \mathrm{O}$ concentrations by gas chromatography (Brooker 450-GC) within 24 hours. And FID detector was used to detect $\mathrm{CH}_{4}$. The detection conditions were as follows: column temperature: $50^{\circ} \mathrm{C}$; detector temperature: $250^{\circ} \mathrm{C}$; nitrogen flow, $10 \mathrm{~mL} / \mathrm{min}$; hydrogen: airflow $30 \mathrm{~mL} / \mathrm{min}, 300 \mathrm{~mL} / \mathrm{min}$. $\mathrm{N}_{2} \mathrm{O}$ was detected with the NI63ECD Detector under the following conditions: detector temperature of $300^{\circ} \mathrm{C}$ and nitrogen flow rate of $300 \mathrm{~mL} / \mathrm{min}$.

$\mathrm{CH}_{4}$ and $\mathrm{N}_{2} \mathrm{O}$ emission flux can be calculated by the following formula:

$F=\rho \times V / A \times d c / d t \times 273 / T,(1)$

Where: $\mathrm{F}$ is the emission flux in units of $\mathrm{mg} \mathrm{m}^{-2} \mathrm{~h}^{-1}\left(\mathrm{CH}_{4}\right), \mu \mathrm{g} \mathrm{m}^{-2} \mathrm{~h}^{-1}\left(\mathrm{~N}_{2} \mathrm{O}\right)$; $\rho$ is the density of $\mathrm{CH}_{4}$ or $\mathrm{N}_{2} \mathrm{O}$ under standard conditions $\left[0.714 \mathrm{~kg} \mathrm{~m}^{-3}\left(\mathrm{CH}_{4}\right)\right.$ and $\left.1.25 \mathrm{~kg} \mathrm{~m}^{-3}\left(\mathrm{~N}_{2} \mathrm{O}\right)\right] ; \mathrm{V}$ is the effective volume in the box $\left(\mathrm{m}^{3}\right)$; $A$ is the sampling box coverage area $\left(\mathrm{m}^{2}\right)$; dc/dt is the changes of $\mathrm{CH}_{4}$ or $\mathrm{N}_{2} \mathrm{O}$ concentration in the sampling tank per unit time $\left[\mu \mathrm{L} \mathrm{L}^{-1} \mathrm{~h}^{-1}\left(\mathrm{CH}_{4}\right)\right.$ and $\left.\mathrm{nL} \mathrm{L} \mathrm{L}^{-1} \mathrm{~h}^{-1}\left(\mathrm{~N}_{2} \mathrm{O}\right)\right]$; $\mathrm{T}$ is the temperature inside the box $(\mathrm{K})$.

\subsection{Calculation of yield, GWP and GHGI}

To analyze the actual effect of the different water control methods on crop yield in the wheat season, production measurement was conducted after crop maturation and the average economic output of the three groups of repeated plots was taken.

GWP was calculated as $\mathrm{CO}_{2}$ equivalents $\left(\mathrm{CO}_{2}\right.$-eq) over a 100-year time horizon using the radiative forcing potential of 298 for $\mathrm{N}_{2} \mathrm{O}$ and 25 for $\mathrm{CH}_{4}$ relative to $\mathrm{CO}_{2}$ (IPCC, 2013):

GWP = cumulative $\mathrm{CH}_{4}$ emission $\times 25+$ cumulative $\mathrm{N}_{2} \mathrm{O}$ emission $\times 298(2) \mathrm{GHGI}=\mathrm{GWP} / \mathrm{Y},(3)$

In the formula: $\mathrm{GHGI}$ is the $\mathrm{GHG}$ emission intensity $\left(\mathrm{t} / \mathrm{hm}^{2}\right.$, calculated as $\left.\mathrm{CO}_{2}\right) ; \mathrm{Y}$ represents the yield of rice and wheat $\left(\mathrm{kg} \mathrm{hm}^{-2}\right)$.

\subsection{Soil properties}

To clarify the mechanism of $\mathrm{CH}_{4}$ production in rice fields, soil properties were analyzed during a complete wheat season. The HW type soil temperature automatic recorder was used to measure the $5 \mathrm{~cm}$ ground temperature. The soil Eh value was determined by in-situ measurement with an Eh meter. The model of the intelligent portable redox potential meter is QX6530, provided by the Nanjing Institute of Soil Science, Chinese Academy of Sciences. We used soil drills in the community to randomly sample fresh soil samples of 0-20 cm from 3 locations The Eh electrode was inserted 3-5 cm below the soil surface. After each removal, we quickly inserted the electrode into the soil sample to a depth of about $2 \mathrm{~cm}$, the Eh value was recorded after the reading became stable.

In each study area, a soil drill was used to take field soil samples from 5 points $0-20 \mathrm{~cm}$ soil layer using the "Z" method. The soil pH was measured by the potentiometric method (water-soil ratio: 2.5:1), and soil organic matter 
was determined by the potassium dichromate volumetric method with oil bath heating.

\subsection{Statistical analysis}

Microsoft Excel 2010 was used to calculate the data on $\mathrm{CH}_{4}$ and $\mathrm{N}_{2} \mathrm{O}$ emissions. Figures were plotted by Origin 8.5. The correlation of $\mathrm{CH}_{4}$ emission flux was subjected to Pearson correlation analysis.

\section{Results}

\section{1. $\mathrm{CH}_{4}$ emissions}

$\mathrm{CH}_{4}$ emissions from rice-wheat rotation system were mainly in the rice season, while drainage during the wheat season effectively reduced the $\mathrm{CH}_{4}$ emissions in the middle and late stages in the rice season (Fig. 2 and Table 5). $\mathrm{CH}_{4}$ emission flux from rice fields of CG showed many peaks after applying fertilization (Table 4), while the $\mathrm{CH}_{4}$ emission flux of SD and DD generally had single peaks during the rice season.

In the rice season, compared with that of $\mathrm{CG}$, the cumulative $\mathrm{CH}_{4}$ emissions of $\mathrm{SD}$ and DD were reduced by $56.36 \%$ and $53.88 \%$ in $2013,74.95 \%$ and $72.03 \%$ in 2014 , and $73.19 \%$ and $70.97 \%$ in 2015 , respectively. The results showed that the $\mathrm{CH}_{4}$ emissions of paddy fields of SD and DD were significantly less than those of CG $\left(P<0.05\right.$, Table 5), while there was no significant difference between SD and DD $(P>0.05)$. In addition, $\mathrm{CH}_{4}$ emissions from rice seasons in the last two years declined significantly, and the cumulative $\mathrm{CH}_{4}$ emissions in 2014 and 2015 were reduced by $56.24 \%$ and $50.64 \%$ (average value for each treatment), respectively, compared with 2013. Relatively speaking, the $\mathrm{CH}_{4}$ emission reduction effect of SD in the rice season was slightly better than that of DD. Although the $\mathrm{CH}_{4}$ emissions in the wheat season were low, they still existed, while drainage also significantly reduced $\mathrm{CH}_{4}$ emissions during the wheat season. The total $\mathrm{CH}_{4}$ emissions of SD and DD were significantly reduced by $139.66 \%$ and $59.48 \%$ in $2013,93.11 \%$ and $94.09 \%$ in 2014 , and $82.59 \%$ and $74.34 \%$ in 2015, respectively $(P<0.05)$.

Table 5

Cumulative $\mathrm{CH}_{4}$ emissions in each treatment during the rice-wheat season $\left(\mathrm{kg} / \mathrm{hm}^{2}\right)$

\begin{tabular}{|c|c|c|c|c|c|c|}
\hline \multirow[t]{2}{*}{ Treatments } & \multicolumn{3}{|l|}{2013} & \multicolumn{2}{|c|}{2015} & \multirow[b]{2}{*}{$\begin{array}{l}\text { Wheat } \\
\text { season }\end{array}$} \\
\hline & Rice season & $\begin{array}{l}\text { Wheat } \\
\text { season }\end{array}$ & Rice season & $\begin{array}{l}\text { Wheat } \\
\text { season }\end{array}$ & Rice season & \\
\hline CG & $330.44 \pm 11.32^{a}$ & $2.32 \pm 1.02^{a}$ & $180.08 \pm 27.22^{a}$ & $3.05 \pm 1.27^{a}$ & $198.64 \pm 14.06^{a}$ & $\begin{array}{l}3.39 \pm \\
1.34^{a}\end{array}$ \\
\hline SD & $144.22 \pm 14.22^{b}$ & $-0.92 \pm 0.12^{c}$ & $45.03 \pm 7.01^{b}$ & $0.21 \pm 0.05^{b}$ & $53.25 \pm 3.24^{b}$ & $0.59 \pm 0.13^{b}$ \\
\hline DD & $152.43 \pm 18.10^{b}$ & $0.94 \pm 0.32^{b}$ & $49.29 \pm 13.90^{b}$ & $0.18 \pm 0.07^{b}$ & $57.67 \pm 3.52^{b}$ & $0.87 \pm 0.12^{b}$ \\
\hline
\end{tabular}


The seasonal variation of $\mathrm{N}_{2} \mathrm{O}$ flux of SD and DD were approximately the same as that of CG (Fig. 3). In the wheat season, SD and DD treatments led to no significant emission reduction compared with CG. In some periods, the $\mathrm{N}_{2} \mathrm{O}$ flux of SD and DD was significantly higher than that of CG. In contrast, during the rice season, both SD and DD effectively reduced $\mathrm{N}_{2} \mathrm{O}$ emissions, and the cumulative $\mathrm{N}_{2} \mathrm{O}$ emissions of SD and DD were reduced by $35.71 \%$ and $53.57 \%$ in $2013,20.51 \%$ and $6.41 \%$ in 2014 , and $43.64 \%$ and $3.64 \%$ in 2015 , respectively, with the decrease of SD reaching a significant level in the three years $(P<0.05)$.

Over the entire rice-wheat rotation system, the cumulative $\mathrm{N}_{2} \mathrm{O}$ emissions in the three years were $D D>C G>S D$ (Table 6). Compared with CG, the cumulative $\mathrm{N}_{2} \mathrm{O}$ emissions of SD declined by $8.50 \%$, while DD increased by $24.38 \%$. Although water management in the wheat season effectively reduced the total $\mathrm{CH}_{4}$ emissions in the rice season, the $\mathrm{N}_{2} \mathrm{O}$ emissions in the wheat season were not lower than those under the conventional treatment, and the cumulative $\mathrm{N}_{2} \mathrm{O}$ emissions even exceeded those under the conventional treatment in some stages.

Table 6

Cumulative $\mathrm{N}_{2} \mathrm{O}$ emissions in each treatment during the rice-wheat season $\left(\mathrm{kg} / \mathrm{hm}^{2}\right)$

\begin{tabular}{|lllllll|}
\hline Treatments & 2013 & \multicolumn{2}{c}{2014} & & & 2015 \\
\cline { 2 - 6 } & $\begin{array}{l}\text { Rice } \\
\text { season }\end{array}$ & $\begin{array}{l}\text { Wheat } \\
\text { season }\end{array}$ & $\begin{array}{l}\text { Rice } \\
\text { season }\end{array}$ & Wheat season & Rice season & Wheat season \\
\hline CG & $0.28 \pm 0.16^{\mathrm{a}}$ & $1.36 \pm 0.46^{\mathrm{c}}$ & $1.56 \pm 0.52^{\mathrm{a}}$ & $1.19 \pm 0.54^{\mathrm{a}}$ & $0.55 \pm 0.20^{\mathrm{a}}$ & $4.00 \pm 1.76^{\mathrm{a}}$ \\
\hline SD & $0.18 \pm 0.11^{\mathrm{b}}$ & $2.35 \pm 1.87^{\mathrm{b}}$ & $1.24 \pm 0.46^{\mathrm{c}}$ & $0.82 \pm 0.26^{\mathrm{b}}$ & $0.31 \pm 0.10^{\mathrm{b}}$ & $3.28 \pm 0.81^{\mathrm{b}}$ \\
\hline DD & $0.13 \pm 0.09^{\mathrm{c}}$ & $3.53 \pm 1.21^{\mathrm{a}}$ & $1.46 \pm 0.33^{\mathrm{b}}$ & $0.95 \pm 0.44^{\mathrm{b}}$ & $0.53 \pm 0.23^{\mathrm{a}}$ & $4.52 \pm 1.62^{\mathrm{a}}$ \\
\hline
\end{tabular}

\subsection{GWP, yield, and GHGI}

The cumulative $\mathrm{CH}_{4}$ emissions during the rice season was the main contributor to GWP of rice-wheat rotation system, and the GWP produced by $\mathrm{CH}_{4}$ in the rice season accounted for $86.01 \%, 71.35 \%$, and $65.85 \%$, respectively, among the total processed by CG, SD and DD (Tables 7 and 8). The GWP calculated with the $\mathrm{CH}_{4}$ and $\mathrm{N}_{2} \mathrm{O}$ emissions after the SD and DD treatments in 2013 was about half that after the CG treatment, with more than 98\% caused by $\mathrm{CH}_{4}$. In 2014, the GWP generated by $\mathrm{CH}_{4}$ and $\mathrm{N}_{2} \mathrm{O}$ after the SD and DD treatments were about onethird that after the CG treatment, and the GWP of all the treatments was reduced to different extents compared with that in 2013. Compared with the other two years, the GWP generated by $\mathrm{CH}_{4}$ in the rice season in 2014 accounted for a relatively small proportion of the total GWP, especially in the SD and DD treatments wherein the percentage was approximately $75 \%$, and SD treatment achieved the best emission reduction effect.

The drainage experiment improved the economic yields of both rice and wheat fields. The yields increased by $3.28 \%$ (SD) and $2.88 \%$ (DD) in the rice season, and increased by $7.64 \%$ (SD) and $4.71 \%$ (DD) in the wheat season, respectively. In addition, the GHGI can reflect the comprehensive impact of different treatments on crop yields and GHG emissions. In the rice season, the GHGI of SD and DD declined by $65.46 \%$ and $62.49 \%$, respectively (threeyear total) $(\mathrm{P}<0.05)$. Moreover, the GHGI of SD declined by $18.75 \%$ and $\mathrm{GHGI}$ of DD rose by $25.00 \%$ in the wheat season $(P<0.05)$. 
Table 7

Integrated greenhouse effect in the rice and wheat seasons in each treatment in the three years

\begin{tabular}{|c|c|c|c|c|c|c|c|c|}
\hline \multicolumn{2}{|c|}{ Treatments } & $\begin{array}{l}\mathrm{CO}_{2}-\mathrm{e} \\
\left(\mathrm{CH}_{4}\right)\end{array}$ & $\begin{array}{l}\text { Percentage } \\
\%\end{array}$ & $\begin{array}{l}\mathrm{CO}_{2} \mathrm{e} \\
\left(\mathrm{N}_{2} \mathrm{O}\right)\end{array}$ & \multirow{2}{*}{$\begin{array}{l}\text { Percentage } \\
\%\end{array}$} & \multicolumn{2}{|c|}{ Total $\mathrm{CO}_{2} \mathrm{e}$} & \multirow{2}{*}{$\begin{array}{l}\text { Percentage reduction } \\
\%\end{array}$} \\
\hline 2013 & CG & 8319.12 & 94.45 & 488.72 & & 8807.72 & & \\
\hline & SD & 3582.52 & 82.61 & 753.94 & 17.39 & 4336.44 & 50.77 & \\
\hline & DD & 3834.25 & 77.85 & 1090.68 & 22.15 & 4924.93 & 44.08 & \\
\hline \multirow[t]{3}{*}{2014} & CG & 4578.25 & 84.82 & 819.52 & 15.18 & 5397.75 & & \\
\hline & SD & 1131.23 & 64.82 & 613.88 & 35.18 & 1744.88 & 67.67 & \\
\hline & $\mathrm{DD}$ & 1236.75 & 63.26 & 718.18 & 36.74 & 1954.93 & 63.78 & \\
\hline \multirow[t]{3}{*}{2015} & CG & 5050.75 & 78.84 & 1355.92 & 21.16 & 6406.65 & & \\
\hline & $S D$ & 1346.32 & 55.72 & 1069.82 & 44.28 & 2415.82 & 62.29 & \\
\hline & $\mathrm{DD}$ & 1463.51 & 49.30 & 1504.91 & 50.70 & 2968.4 & 53.67 & \\
\hline
\end{tabular}

Table 8

Average yield $\left(\mathrm{kg} \mathrm{hm}^{-2}\right)$ and yield-scaled GWP $\left(\mathrm{kg} \mathrm{CO}_{2}-\mathrm{Eq} \mathrm{kg}^{-1}\right)$ in the rice-wheat seasons in each treatment

\begin{tabular}{|lllllll|}
\hline & Treatments & $\mathrm{CO}_{2}-\mathbf{e}\left(\mathrm{CH}_{4}\right)$ & $\mathrm{CO}_{2}-\mathbf{e}\left(\mathrm{N}_{2} \mathbf{O}\right)$ & GWP & Yield & GHGI \\
\hline Rice season & $\mathrm{CG}$ & $5909.67^{\mathrm{a}}$ & $237.40^{\mathrm{a}}$ & $6147.07^{\mathrm{a}}$ & $8104.42^{\mathrm{a}}$ & $0.76^{\mathrm{a}}$ \\
\cline { 2 - 6 } & $\mathrm{SD}$ & $2020.87^{\mathrm{b}}$ & $171.83^{\mathrm{c}}$ & $2192.71^{\mathrm{b}}$ & $8370.12^{\mathrm{a}}$ & $0.26^{\mathrm{b}}$ \\
\cline { 2 - 7 } & $\mathrm{DD}$ & $2161.63^{\mathrm{b}}$ & $210.57^{\mathrm{b}}$ & $2372.20^{\mathrm{b}}$ & $8337.74^{\mathrm{a}}$ & $0.28^{\mathrm{b}}$ \\
\hline Wheat season & $\mathrm{CG}$ & $73.03^{\mathrm{a}}$ & $650.63^{\mathrm{c}}$ & $723.67^{\mathrm{b}}$ & $4433.31^{\mathrm{a}}$ & $0.16^{\mathrm{b}}$ \\
& $\mathrm{SD}$ & $-0.97^{\mathrm{c}}$ & $640.70^{\mathrm{b}}$ & $639.73^{\mathrm{c}}$ & $4772.22^{\mathrm{a}}$ & $0.13^{\mathrm{c}}$ \\
\cline { 2 - 7 } & $\mathrm{SD}$ & $16.60^{\mathrm{b}}$ & $894.00^{\mathrm{a}}$ & $910.60^{\mathrm{a}}$ & $4642.24^{\mathrm{a}}$ & $0.20^{\mathrm{a}}$ \\
\hline
\end{tabular}

\subsection{Main factors affecting $\mathrm{CH}_{4}$ emission}

\subsubsection{Atmospheric temperature and $5 \mathrm{~cm}$ ground temperature}

The seasonal variation of $\mathrm{CH}_{4}$ flux was significantly correlated with the average atmospheric temperature in the whole growth period of rice $(\mathrm{r}=0.62, \mathrm{df}=35, \mathrm{P}<0.05)$. The $\mathrm{CH}_{4}$ emission flux of the paddy field was mostly at a low level when the temperature was lower than $26^{\circ} \mathrm{C}$, while it showed a significant upward trend when the ambient temperature exceeded $30^{\circ} \mathrm{C}$.

In the early stage of rice growth (0-28 days before rice field sunning), the trend of the $5 \mathrm{~cm}$ ground temperature and $\mathrm{CH}_{4}$ flux in the paddy soil was approximately the same (Fig. 4). The soil drying period in the field was 
between 29th and 34th days after transplanting. During this period, the paddy field surface water was evaporated, wherein the soil permeability and the oxygen content in the soil void increased, and then the soil environment changed from anaerobic to aerobic state, inhibiting the activity of methanogens, and finally reducing the $\mathrm{CH}_{4}$ emissions. Accordingly, no significant correlation existed between the $\mathrm{CH}_{4}$ emissions and $5 \mathrm{~cm}$ ground temperature. Generally, during the whole growth period of rice, the $\mathrm{CH}_{4}$ emissions of paddy soil were significantly correlated with the $5 \mathrm{~cm}$ ground temperature.

As shown in Fig. 5, the correlation between the change in $\mathrm{CH}_{4}$ emission flux and the $5 \mathrm{~cm}$ ground temperature was significant $(\mathrm{P}<0.01)$. As the $5 \mathrm{~cm}$ ground temperature increased, $\mathrm{CH}_{4}$ emissions also increased gradually.

According to the comparison of the $\mathrm{R}^{2}$ value between the $5 \mathrm{~cm}$ ground temperature and the $\mathrm{CH}_{4}$ flux in the watercontrolled farmland, the fitting degree of each treatment was higher ( 0.7 or higher), indicating that the $5 \mathrm{~cm}$ ground temperature plays an important role in the change in $\mathrm{CH}_{4}$ flux.

Figure 5. Relationship between the $\mathrm{CH}_{4}$ emission flux and $5 \mathrm{~cm}$ ground temperature in each treatment.

\subsubsection{Soil properties}

The corresponding Eh values were mostly between -150 and -300 mV when the $\mathrm{CH}_{4}$ emission flux was higher; when the soil Eh value was lower than $-150 \mathrm{mV}$, the $\mathrm{CH}_{4}$ emission flux increased significantly with the decrease of Eh; whereas the corresponding $\mathrm{CH}_{4}$ emission flux was close to zero when the Eh value was higher than $-100 \mathrm{mV}$ (Fig. 6-a, b, c).

In the wheat season, the changes in soil organic matter $(28.20-26.59 \mathrm{~g} / \mathrm{Kg})$ and soil pH (5.79-6.12) of CG were relatively more stable. In contrast, the soil organic carbon content of both SD and DD showed declining trends, among which the soil organic matter of SD dropped from $29.6 \mathrm{~g} / \mathrm{Kg}$ to $14.75 \mathrm{~g} / \mathrm{Kg}$ while that of DD dropped from $28.62 \mathrm{~g} / \mathrm{Kg}$ to $16.68 \mathrm{~g} / \mathrm{Kg}$. The lowland soil in Chao Lake area was an acidic soil type, and it was observed that the drainage would raise the soil pH: The soil pH of SD increased from 5.29 to 6.67 while that of DD increased from 5.15 to 6.41 (Fig. 7-a, b).

\section{Discussion}

\section{1. $\mathrm{CH}_{4}$ emissions}

In this study, the annul emissions of $\mathrm{CH}_{4}$ were lower than those in the study from the subtropical permanently flooded rice paddy fields of China (Zhou et al. 2018). Compared with $\mathrm{CG}$, the cumulative $\mathrm{CH}_{4}$ emissions from the rotation system in the rice season were reduced by $56.36 \%, 74.99 \%$ and $73.19 \%$ (SD), and $53.87 \%, 72.63 \%$ and 70.97\% (DD) in 2012-2013, 2013-2014 and 2014-2015, respectively $(P<0.01)$. It can be concluded that SD and DD are very stable in reducing $\mathrm{CH}_{4}$ emissions, so they can be regarded as effective measures for $\mathrm{CH}_{4}$ emission reduction of rice-wheat rotation system.

The cumulative $\mathrm{CH}_{4}$ emissions in the first year were notably too high in this study (Table 5), which could be attributed to the fact that the drainage released the $\mathrm{CH}_{4}$ originally stored in the soil and improved the aerobic state of the soil, not only inhibiting the production of $\mathrm{CH}_{4}$, but also increasing the activity of methane oxidizing bacteria. 
The existence of a large number of anaerobic zones in the soil structure during the initial drainage stage is suitable for the production of $\mathrm{CH}_{4}$ (Yuan et al. 2016). Furthermore, through the comparison of the $\mathrm{CH}_{4}$ emissions in the three years, it was found that multiple peaks often existed in the early and late stages of rice growth (Fig. 3), and they all appeared after applying fertilization (Tables 2 and 3 and 4), suggesting that the application of fertilizer provided an excessive carbon source to the soil in a short time, thus promoting the emissions of $\mathrm{CH}_{4}$, consistent with the finding of previous research (Fan et al. 2016; Masuda et al. 2018). Over the entire rice-wheat rotation system, it can be seen that the peaks of $\mathrm{N}_{2} \mathrm{O}$ flux in the rice season roughly coincided with the low value of $\mathrm{CH}_{4}$ flux, all in the period of rice field sunning. $\mathrm{CH}_{4}$ tends to be generated under anaerobic conditions (Cai et al. 1997). During the period of rice field sunning, the $\mathrm{CH}_{4}$ emissions are very low due to the soil aeration enhanced by rice field sunning, which destroy the extreme anaerobic environment of methanogens (Nayak et al. 2015). Therefore, rice field sunning can be regarded as an effective measure for $\mathrm{CH}_{4}$ emission reduction in paddy fields.

Temperature mainly controls $\mathrm{CH}_{4}$ emissions and absorption by affecting the activity against methanogens and methane oxidizing bacteria (Green et al. 2018). The soil Eh is a characterization of the soil moisture status of the soil oxygen availability. Gas exchange is reduced between the atmosphere and the soil when the soil is flooded (Nobrega et al. 2016). Accordingly, the soil is in an extremely anaerobic environment, wherein the soil Eh decreases rapidly and the production activity of $\mathrm{CH}_{4}$ bacteria is enhanced. Under flooding conditions, polysaccharides in the paddy fields produce a large amount of acetic acid, $\mathrm{H}_{2}$, and $\mathrm{CO}_{2}$ during the decomposition process, which offer abundant basic substances to the production of $\mathrm{CH}_{4}$ bacteria, thereby significantly increasing the $\mathrm{CH}_{4}$ emission flux of the rice fields (Nobrega et al. 2016). The corresponding Eh values were mostly between -150 and $-300 \mathrm{mV}$ when the $\mathrm{CH}_{4}$ emission flux was high in this study, indicating that $-150 \mathrm{mV}$ may be the critical value affecting the $\mathrm{CH}_{4}$ emission flux in lowland paddy soils. However, due to the complicated field conditions, the relationship between $\mathrm{CH}_{4}$ emissions and soil Eh has not been definitely clarified. SzafranekNakonieczna and Stępniewska (2015) reported that when the soil Eh value is less than $240 \mathrm{mV}$, the $\mathrm{CH}_{4}$ production and emission will be concentrated, inconsistent with the results of this study. The discrepancy among these results may be due to differences in soil texture.

Ferrari Machado et al. (2021) and Quang et al. (2019) reported that soil environmental factors are the main factors affecting the GWP of the rice-wheat rotation system. Methanogens and methane oxidizing bacteria are ubiquitous in paddy soils where they are affected by the physical and chemical properties of the soil. Under flooding conditions, a series of simple organic compounds are produced by the ferment of soil organic matters. These simple compounds prone to mineralization are the carbon source and energy source for $\mathrm{CH}_{4}$ production. $\mathrm{CH}_{4}$ in rice fields is mainly produced by the decomposition of soil organic matter in those soils by methanogens in the soil under anaerobic conditions (Takakai et al. 2019; Yuan et al. 2018). Both SD and DD reduce soil organic matter content, and low organic matter content may inhibit the activities of methanogens. Related research has revealed a significant positive correlation between $\mathrm{CH}_{4}$ emission flux and soil organic matter content (Pramanik et al. 2014). The results of this study indicated that the reduction of organic matter caused by drainage may be the dominant reason for $\mathrm{CH}_{4}$ emissions. The possible reason is that after soil flooding, anaerobic decomposition of organic matter is dominated, and microorganisms deprive the organic matter of oxygen in the soil to form various reducing substances, resulting in a rapid decline of soil Eh. The faster the Eh value declines, the more the reducing substances will be produced (Verdi et al. 2018). 
Moreover, soil pH significantly influences the activities and growth of methanogens and methane oxidizing bacteria that control $\mathrm{CH}_{4}$ production and oxidation, respectively. Some studies have demonstrated that methanogens have the ability to adapt to acidic environments (Lin et al. 2017; Wu et al. 2018). In this study, drainage in the wheat season led to an increase in soil $\mathrm{pH}$, and lower $\mathrm{CH}_{4}$ emissions were observed in the rice season, consistent with the findings by Jeffery et al. (2016) that the increase in soil pH is conducive to the survival of methane oxidizing bacteria, thus reducing the $\mathrm{CH}_{4}$ emissions. However, another study reported that an increase in soil pH will promote the activity of methanogens (Liu et al. 2011). There are also reports that the production of $\mathrm{CH}_{4}$ is affected by a combination of various soil properties (Shen et al. 2021). Therefore, effects of other soil properties should be considered when the effects of organic matters on $\mathrm{CH}_{4}$ emissions are assessed.

\section{2. $\mathrm{N}_{2} \mathrm{O}$ emissions}

Soil moisture regimes are important for the activities of nitrifying and denitrifying bacterial enzymes, major drivers of $\mathrm{N}_{2} \mathrm{O}$ emissions (Cai et al. 1997; Lan et al. 2013). Notably, since flooding conditions will stimulate the denitrification process of soil nitrate nitrogen, the $\mathrm{N}_{2} \mathrm{O}$ emissions of each treatment increase to varying degrees. Drainage in the wheat season has a certain inhibitory effect on $\mathrm{CH}_{4}$ emissions, but the content of $\mathrm{N}_{2} \mathrm{O}$ is increased compared with that under the conventional treatment, because water management affects the content of $\mathrm{O}_{2}$ in the soil, weakening anaerobic condition of soil gradually and promoting nitrification (Zhang et al. 2021). When the soil is in an alternating aerobic and anaerobic condition, its moderate $\mathrm{O}_{2}$ concentration is conducive to the production of $\mathrm{N}_{2} \mathrm{O}$ in the nitrification and denitrification processes, which leads to massive $\mathrm{N}_{2} \mathrm{O}$ production and emissions (Song et al. 2020; Vilarrasa-Nogue et al. 2020; Wang et al. 2017). Therefore, the dry and wet alternation of the soil caused by drainage satisfies both the above conditions and greatly promotes the emission of $\mathrm{N}_{2} \mathrm{O}$, and wheat field soils have the largest amount of emissions (Liao et al. 2020; Xu et al. 2013). In the wheat season, the peak of $\mathrm{N}_{2} \mathrm{O}$ emissions of each treatment emerged after fertilization. Abalos et al. (2016) and Wang et al. (2021) reported that applying fertilization will produce a large amount of nitrogen to the soil, which provide a reaction substrate for nitrifying and denitrifying bacteria. Affected by the typhoon bringing frequent rainfall in 2015, the soil was in aerobic and anaerobic alternation, which promoted the process of nitrification and denitrification, so the $\mathrm{N}_{2} \mathrm{O}$ emissions greatly increased and fluctuated (Gao et al. 2018; Hou et al. 2016), directly leading to a significant increase in $\mathrm{N}_{2} \mathrm{O}$ emissions of rice-wheat rotation system in 2015 (Table 7). In order to further clarify the mechanism of $\mathrm{N}_{2} \mathrm{O}$ emissions, it is necessary to study the impact of rainfall pattern on $\mathrm{N}_{2} \mathrm{O}$ emissions.

Dryland soil has great porosity, making the oxygen easily get in, so the extreme anaerobic environment required for the survival of methanogens is blocked, while the activity of methanotrophic bacteria is preserved (Hofmann et al. 2016). Liu et al. (2015) reported that winter-wheat fields are often regarded as the $\operatorname{sink}$ of $\mathrm{CH}_{4}$. In this experiment, $\mathrm{CH}_{4}$ emissions in the wheat season were very low but should not be ignored (Table 5). It is worth noting that the $\mathrm{CH}_{4}$ emissions of rice-wheat rotation farmland in this study were too high, while the $\mathrm{N}_{2} \mathrm{O}$ emissions were considerably low. Wen et al. (2017) reported that the substantial reduction of $\mathrm{N}_{2} \mathrm{O}$ to $\mathrm{N}_{2}$ under anaerobic condition may lead to lower $\mathrm{N}_{2} \mathrm{O}$ emissions. The lowland polder areas along the middle and lower reaches of the Yangtze River are mostly derived from the development of water, and the groundwater level is strongly affected by the nearby main waters (Huang et al. 2016). It has been reported that groundwater level fluctuation is a key predictor for $\mathrm{CH}_{4}$ and $\mathrm{N}_{2} \mathrm{O}$ emissions from cultivated lowland (Wen et al. 2020). Evans et al.

Page $12 / 26$ 
(2021) observed that the high groundwater level in lowland areas usually leads to $\mathrm{CH}_{4}$ increase and $\mathrm{N}_{2} \mathrm{O}$ decrease, which is a scientific issue that cannot be ignored in global climate change. Therefore, in arable lands with different groundwater levels, the effect of water control treatments on the total greenhouse effect caused by $\mathrm{CH}_{4}$ and $\mathrm{N}_{2} \mathrm{O}$ needs to be further assessed. For the further exploration of the GHG emission reduction technologies applicable to lowland polder areas, it is suggested that long-term observations be conducted on soil water content and groundwater levels in the future to study the specific mechanisms of water control and emissions reduction.

\subsection{Yield, GWP, and GHGI}

The previous studies mainly focused on the cumulative emission and integrative GWP of $\mathrm{CH}_{4}$ and $\mathrm{N}_{2} \mathrm{O}$ from the paddy fields. Although there are related reports on the assessment of GHG in the entire rice-wheat rotation system, that in the lowland polder area remains unclear ( $\mathrm{Li}$ et al. 2021). China's subtropical regions are widely planted with rice, but it has always been a difficult point in related research to ensure stable crop production or even production increase when reducing GHG emissions from rice paddy soils.

Among the total GWP treated by CG, SD, and DD, the contribution rate of $\mathrm{CH}_{4}$ was $86.01 \%, 71.35 \%$, and $65.85 \%$, respectively, in this study. Therefore, the most effective way to reduce the total amount of GHG in rice fields is usually to reduce $\mathrm{CH}_{4}$ emissions (Lagomarsino et al. 2016). Jiang et al. (2019) pointed out that compared with continuous submerged irrigation, non-continuous submerged irrigation effectively reduces the GWP of rice fields by $44 \%$. In south China, after adopting mid-term drainage in the double-cropping rice planting area, the GWP in the early and late rice seasons are reduced by $22 \%$ and $41 \%$, respectively (Liang et al. 2017). Drainage in the wheat season significantly reduces the GWP of the entire rice-wheat rotation system, even with increased $\mathrm{N}_{2} \mathrm{O}$ emissions in some years, and the net GWP of the entire system has dramatically declined because of significantly reduced $\mathrm{CH}_{4}$ emissions. In this study, it was found that the yield of rice increased, because drainage can improve the soil permeability of the paddy field, and the oxygen supply is sufficient, creating good growth conditions for the rice, so the $\mathrm{GHGI}$ of the entire rice-wheat rotation system was significantly reduced. In general, based on the current situation that a large amount of fertilizers are used to increase production and environmental protection is neglected, the drainage is a planting technique worth promoting.

\section{Conclusion}

The $\mathrm{CH}_{4}$ emissions in the rice season were the main contributor to GWP of the rice-wheat rotation cropping system. The $\mathrm{CH}_{4}$ and $\mathrm{N}_{2} \mathrm{O}$ emissions of the rice-wheat rotation system were obviously affected by drainage. Compared with those of CG, the $\mathrm{CH}_{4}$ cumulative emissions of SD and DD were reduced by $65.80 \%$ and $63.42 \%$ (rice season), and $101.37 \%$ and $77.28 \%$ (wheat season), respectively, while the $\mathrm{N}_{2} \mathrm{O}$ emissions increased in some years. Drainage led to an increase in the yields of both rice and wheat. In the rice season, the GHGI of SD and DD reduced by $65.46 \%$ and $62.49 \%$, respectively (three-year total) $(\mathrm{P}<0.05)$. The $\mathrm{GHGI}$ of SD declined by $18.75 \%$ and GHGI of DD rose by $25.00 \%$ in the wheat season. It can be inferred that SD and DD ensure stably increasing production and effectively reduce $\mathrm{GHG}$ emissions. The $\mathrm{CH}_{4}$ emission flux was significantly positively correlated with air temperature and $5 \mathrm{~cm}$ ground temperature, but negatively correlated with soil Eh. When the soil Eh value was lower than $-150 \mathrm{mV}$, the $\mathrm{CH}_{4}$ emission flux increased markedly with the decrease of Eh. In addition, both SD and DD led to marked decrease in soil organic matter content and an increase in soil $\mathrm{pH}$, which may be the reason for decreased $\mathrm{CH}_{4}$ emissions. 


\section{Declarations}

\section{Acknowledgments}

Non-profit industry (agriculture) scientific research special project "Agricultural source greenhouse gas monitoring and control technology research" (201103039)

\section{Declaration of Interest Statement}

The authors declare that they have no known competing financial interests that could have appeared to influence the work reported in this paper.

\section{Data availability}

All data analyzed during the study are included in this article.

\section{Credit Author Statement}

Hao He: Sampling, Measuring, Data curation, Writing - original draft, Writing - review \& editing.

Dandan Li, Ze Wu, Tiancheng Zhang, Feifan Pan, Fengwen Wang: Sampling, Measuring, Formal analysis.

Shuyun Yang, Youhua Ma : Methodology, Supervision, Writing- review and Editing.

\section{Ethics declarations}

Consent to participate

All authors voluntarily participate in this research study.

\section{Consent to publish}

All authors consent to the publication of the manuscript.

\section{Conflict of interest}

The authors declare no competing interests.

\section{References}

Abalos D, Smith WN, Grant BB, Drury CF, MacKell S, Wagner-Riddle C (2016) Scenario analysis of fertilizer management practices for N2O mitigation from corn systems in Canada Sci Total Environ 573:356-365 doi:10.1016/j.scitotenv.2016.08.153

Banger K, Tian H, Lu C (2012) Do nitrogen fertilizers stimulate or inhibit methane emissions from rice fields? Global Change Biology 18:3259-3267 doi:10.1111/j.1365-2486.2012.02762.x

Cai Z, Xing G, Yan X, Xu H, Tsuruta H, Yagi K, Minami K (1997) Methane and nitrous oxide emissions from rice paddy fields as affected by nitrogen fertilisers and water management Plant \& Soil 196:7-14 
Cai ZC, Tsuruta H, Minami K (2000) Methane emission from rice fields in China: measurements and influencing factors Journal of Geophysical Research Atmospheres 105:17231-17242

Cheng $\mathrm{H}$ et al. (2021) Effects of residue removal and tillage on greenhouse gas emissions in continuous corn systems as simulated with RZWQM2 Journal of Environmental Management 285:112097 doi:https://doi.org/10.1016/j.jenvman.2021.112097

David C, Lemke R, Helgason W, Farrell RE (2018) Current inventory approach overestimates the effect of irrigated crop management on soil-derived greenhouse gas emissions in the semi-arid Canadian Prairies Agricultural Water Management 208:19-32 doi:10.1016/j.agwat.2018.06.006

Evans CD et al. (2021) Overriding water table control on managed peatland greenhouse gas emissions Nature 593:548-552 doi:10.1038/s41586-021-03523-1

Fan X, Yu H, Wu Q, Ma J, Xu H, Yang J, Zhuang Y (2016) Effects of fertilization on microbial abundance and emissions of greenhouse gases (CH4 and N2O) in rice paddy fields Ecol Evol 6:1054-1063 doi:10.1002/ece3.1879

Ferrari Machado PV et al. (2021) Crop residues contribute minimally to spring-thaw nitrous oxide emissions under contrasting tillage and crop rotations Soil Biology and Biochemistry 152 doi:10.1016/j.soilbio.2020.108057

Gao J-Q, Duan M-Y, Zhang X-Y, Li Q-W, Yu F-H (2018) Effects of frequency and intensity of drying-rewetting cycles on Hydrocotyle vulgaris growth and greenhouse gas emissions from wetland microcosms Catena 164:44-49 doi:10.1016/j.catena.2018.01.006

Green SM, Baird AJ, Evans CD, Peacock M, Holden J, Chapman PJ, Smart RP (2018) Methane and carbon dioxide fluxes from open and blocked ditches in a blanket bog Plant and Soil 424:619-638 doi:10.1007/s11104-017-3543z

Haque MM, Biswas JC (2021) Emission factors and global warming potential as influenced by fertilizer management for the cultivation of rice under varied growing seasons Environ Res 197:111156 doi:10.1016/j.envres.2021.111156

Hofmann K, Farbmacher S, Illmer P (2016) Methane flux in montane and subalpine soils of the Central and Northern Alps Geoderma 281:83-89 doi:10.1016/j.geoderma.2016.06.030

Hou H, Yang S, Wang F, Li D, Xu J (2016) Controlled irrigation mitigates the annual integrative global warming potential of methane and nitrous oxide from the rice-winter wheat rotation systems in Southeast China Ecological Engineering 86:239-246 doi:10.1016/j.ecoleng.2015.11.022

Huang J, Gao J, Yan R (2016) A Phosphorus Dynamic model for lowland Polder systems (PDP) Ecological Engineering 88:242-255 doi:10.1016/j.ecoleng.2015.12.033

Huang $Y$ et al. (2018) Greenhouse gas emissions and crop yield in no-tillage systems: A meta-analysis Agriculture, Ecosystems \& Environment 268:144-153 doi:10.1016/j.agee.2018.09.002

Jain N, Dubey R, Dubey DS, Singh J, Khanna M, Pathak H, Bhatia A (2014) Mitigation of greenhouse gas emission with system of rice intensification in the Indo-Gangetic Plains Paddy and Water Environment 12 
Jeffery S, Verheijen FGA, Kammann C, Abalos D (2016) Biochar effects on methane emissions from soils: A metaanalysis Soil Biology and Biochemistry 101:251-258 doi:10.1016/j.soilbio.2016.07.021

Jiang $Y$ et al. (2019) Water management to mitigate the global warming potential of rice systems: A global metaanalysis Field Crops Research 234:47-54 doi:10.1016/j.fcr.2019.02.010

Johnson-Beebout SE, Angeles OR, Alberto MCR, Buresh RJ (2009) Simultaneous minimization of nitrous oxide and methane emission from rice paddy soils is improbable due to redox potential changes with depth in a greenhouse experiment without plants Geoderma 149:45-53 doi:https://doi.org/10.1016/j.geoderma.2008.11.012

Kang G, Cai Z, Feng X (2002) Importance of water regime during the non-rice growing period in winter in regional variation of $\mathrm{CH} 4$ emissions from rice fields during following rice growing period in China Nutrient Cycling in Agroecosystems 64

Khalid MS, Shaaban M, Hu R (2019) N2O, CH4, and CO2 Emissions from Continuous Flooded, Wet, and Flooded Converted to Wet Soils Journal of Soil Science and Plant Nutrition 19:342-351 doi:10.1007/s42729-019-00034-X

Lagomarsino A et al. (2016) Alternate Wetting and Drying of Rice Reduced CH4 Emissions but Triggered N2O Peaks in a Clayey Soil of Central Italy Pedosphere 26:533-548 doi:10.1016/s1002-0160(15)60063-7

Lan T, Han Y, Roelcke M, Nieder R, Cai Z (2013) Processes leading to N2O and NO emissions from two different Chinese soils under different soil moisture contents Plant and Soil 371:611-627 doi:10.1007/s11104-013-1721-1

Li SH, Guo LJ, Cao CG, Li CF (2021) Effects of straw returning levels on carbon footprint and net ecosystem economic benefits from rice-wheat rotation in central China Environ Sci Pollut Res Int 28:5742-5754 doi:10.1007/s11356-020-10914-w

Liang K et al. (2017) Nitrogen losses and greenhouse gas emissions under different $\mathrm{N}$ and water management in a subtropical double-season rice cropping system Sci Total Environ 609:46-57

doi:10.1016/j.scitotenv.2017.07.118

Liang K, Zhong X, Huang N, Lampayan RM, Pan J, Tian K, Liu Y (2016) Grain yield, water productivity and CH 4 emission of irrigated rice in response to water management in south China Agricultural Water Management 163

Liao B, Wu X, Yu Y, Luo S, Hu R, Lu G (2020) Effects of mild alternate wetting and drying irrigation and mid-season drainage on $\mathrm{CH} 4$ and N2O emissions in rice cultivation Sci Total Environ 698:134212 doi:10.1016/j.scitotenv.2019.134212

Lin Z et al. (2017) Effects of Different Biochars on Pinus elliottii Growth, N Use Efficiency, Soil N $2 \mathrm{O}$ and CH 4 Emissions and C Storage in a Subtropical Area of China Pedosphere 27:248-261 doi:10.1016/s10020160(17)60314-x

Linquist B, Groenigen KJ, Adviento-Borbe MA, Pittelkow C, Kessel C (2012) An agronomic assessment of greenhouse gas emissions from major cereal crops Global Change Biology 18:194-209 doi:10.1111/j.13652486.2011.02502.x 
Liu L, Hu C, Yang P, Ju Z, Olesen JE, Tang J (2015) Effects of experimental warming and nitrogen addition on soil respiration and $\mathrm{CH} 4$ fluxes from crop rotations of winter wheat-soybean/fallow Agricultural and Forest Meteorology 207:38-47 doi:10.1016/j.agrformet.2015.03.013

Liu X, Zhou T, Liu Y, Zhang X, Li L, Pan G (2019) Effect of mid-season drainage on CH4 and N2O emission and grain yield in rice ecosystem: A meta-analysis Agricultural Water Management 213:1028-1035 doi:10.1016/j.agwat.2018.12.025

Liu Y, Yang M, Wu Y, Wang H, Chen Y, Wu W (2011) Reducing CH4 and CO2 emissions from waterlogged paddy soil with biochar Journal of Soils and Sediments 11:930-939 doi:10.1007/s11368-011-0376-X

Masuda, Itoh, Shiratori, Senoo (2018) Metatranscriptomic insights into microbial consortia driving methane metabolism in paddy soils Soil Science and Plant Nutrition 64

Montoya-González A et al. (2009) Straw management, crop rotation and nitrogen source effect on carbon and nitrogen dynamics: A laboratory study Plant and Soil 325:243-253 doi:10.1007/s11104-009-9975-3

Nayak D et al. (2015) Management opportunities to mitigate greenhouse gas emissions from Chinese agriculture Agriculture, Ecosystems \& Environment 209:108-124 doi:10.1016/j.agee.2015.04.035

Nillesen AL, Kok M (2015) An integrated approach to flood risk management and spatial quality for a Netherlands' river polder area Mitig Adapt Strateg Glob Chang 20:949-966 doi:10.1007/s11027-015-9675-7

Nobrega GN et al. (2016) Edaphic factors controlling summer (rainy season) greenhouse gas emissions (CO2 and $\mathrm{CH} 4$ ) from semiarid mangrove soils (NE-Brazil) Sci Total Environ 542:685-693

doi:10.1016/j.scitotenv.2015.10.108

Pramanik P, Haque MM, Kim SY, Kim PJ (2014) C and N accumulations in soil aggregates determine nitrous oxide emissions from cover crop treated rice paddy soils during fallow season Sci Total Environ 490:622-628 doi:10.1016/j.scitotenv.2014.05.046

Pratibha G et al. (2016) Net global warming potential and greenhouse gas intensity of conventional and conservation agriculture system in rainfed semi arid tropics of India Atmospheric Environment 145:239-250 doi:10.1016/j.atmosenv.2016.09.039

Quang LX et al. (2019) Effect of organizational paddy water management by a water user group on methane and nitrous oxide emissions and rice yield in the Red River Delta, Vietnam Agricultural Water Management 217:179192 doi:10.1016/j.agwat.2019.02.015

Saarenheimo J, Rissanen AJ, Arvola L, Nykänen H, Lehmann MF, Tiirola M (2015) Genetic and Environmental Controls on Nitrous Oxide Accumulation in Lakes PLOS ONE 10:e0121201 doi:10.1371/journal.pone.0121201

Schimel JP, Wetterstedt JÅM, Holden PA, Trumbore SE (2011) Drying/rewetting cycles mobilize old C from deep soils from a California annual grassland Soil Biology and Biochemistry 43:1101-1103 doi:10.1016/j.soilbio.2011.01.008 
Shen Y, Zhang Z, Xue Y (2021) Study on the new dynamics and driving factors of soil pH in the red soil, hilly region of South China Environ Monit Assess 193:304 doi:10.1007/s10661-021-09080-4

Song $\mathrm{H}$ et al. (2020) A 4-year field measurement of N2O emissions from a maize-wheat rotation system as influenced by partial organic substitution for synthetic fertilizer J Environ Manage 263:110384 doi:10.1016/j.jenvman.2020.110384

Szafranek-Nakonieczna A, Stępniewska Z (2015) The influence of the aeration status (ODR, Eh) of peat soils on their ability to produce methane Wetlands Ecology and Management 23:665-676 doi:10.1007/s11273-015-9410-x

Takakai F, Kominami Y, Ohno S, Nagata O (2019) Effect of the long-term application of organic matter on soil carbon accumulation and GHG emissions from a rice paddy field in a cool-temperate region, Japan. -I.

Comparison of rice straw and rice straw compost Soil Science and Plant Nutrition 66:84-95 doi:10.1080/00380768.2019.1609335

Tellez-Rio A, Garcia-Marco S, Navas M, Lopez-Solanilla E, Tenorio JL, Vallejo A (2015) N2O and CH4 emissions from a fallow-wheat rotation with low $\mathrm{N}$ input in conservation and conventional tillage under a Mediterranean agroecosystem Sci Total Environ 508:85-94 doi:10.1016/j.scitotenv.2014.11.041

Verdi L, Mancini M, Ljubojevic M, Orlandini S, Dalla Marta A (2018) Greenhouse gas and ammonia emissions from soil: the effect of organic matter and fertilisation method Italian Journal of Agronomy 11 doi:10.4081/ija.2018.1124

Vilarrasa-Nogue M, Teira-Esmatges MR, Pascual M, Villar JM, Rufat J (2020) Effect of N dose, fertilisation duration and application of a nitrification inhibitor on GHG emissions from a peach orchard Sci Total Environ 699:134042 doi:10.1016/j.scitotenv.2019.134042

Wang F, Mu Z, Guo T, Huang A, Lin X, Shi X, Ni J (2020) Effect of long-term differentiated fertilisation regimes on greenhouse gas emissions from a subtropical rice-wheat cropping system Plant, Soil and Environment 66:167174 doi:10.17221/693/2019-pse

Wang J et al. (2021) Effects of synthetic nitrogen fertilizer and manure on fungal and bacterial contributions to N2O production along a soil acidity gradient Sci Total Environ 753:142011 doi:10.1016/j.scitotenv.2020.142011

Wang J, Zhang J, Müller C, Cai Z (2017) The Mechanisms of High N2O Emissions from Greenhouse Vegetable Field Soils CLEAN - Soil, Air, Water 45 doi:10.1002/clen.201600210

Wen Y, Corre MD, Rachow C, Chen L, Veldkamp E (2017) Nitrous oxide emissions from stems of alder, beech and spruce in a temperate forest Plant and Soil 420:423-434 doi:10.1007/s11104-017-3416-5

Wen Y, Freeman B, Ma Q, Evans CD, Chadwick DR, Zang H, Jones DL (2020) Raising the groundwater table in the non-growing season can reduce greenhouse gas emissions and maintain crop productivity in cultivated fen peats Journal of Cleaner Production 262 doi:10.1016/j.jclepro.2020.121179

Wu L, Wu X, Shaaban M, Zhou M, Zhao J, Hu R (2018) Decrease in the annual emissions of CH4 and N2O following the initial land management change from rice to vegetable production Environ Sci Pollut Res Int 25:13014-13025 doi:10.1007/s11356-018-1559-4

Page 18/26 
Xu H, Cai Z, Tsuruta H (2003) Soil Moisture between Rice-Growing Seasons Affects Methane Emission, Production, and Oxidation. doi:10.2136/sssaj2003.1147

Xu J-Z, Peng S-Z, Hou H-J, Yang S-H, Luo Y-F, Wang W-G (2013) Gaseous losses of nitrogen by ammonia volatilization and nitrous oxide emissions from rice paddies with different irrigation management Irrigation Science 31

Xu Z, Xie YX, Xiong ZQ, Yan XY, Xing GX, Zhu ZL (2009) Nitrogen fate and environmental consequence in paddy soil under rice-wheat rotation in the Taihu lake region, China Plant \& Soil 319:225-234

Yuan Q, Hernández M, Dumont MG, Rui J, Fernández Scavino A, Conrad R (2018) Soil bacterial community mediates the effect of plant material on methanogenic decomposition of soil organic matter Soil Biology and Biochemistry 116:99-109 doi:10.1016/j.soilbio.2017.10.004

Yuan Y, Dai X, Wang H, Xu M, Fu X, Yang F (2016) Effects of Land-Use Conversion from Double Rice Cropping to Vegetables on Methane and Nitrous Oxide Fluxes in Southern China PLoS One 11:e0155926 doi:10.1371/journal.pone.0155926

Zhang W, Li H, Xiao Q, Li X (2021) Urban rivers are hotspots of riverine greenhouse gas (N2O, CH4, CO2) emissions in the mixed-landscape chaohu lake basin Water Res 189:116624 doi:10.1016/j.watres.2020.116624

Zhao X, Xie Y-x, Xiong Z-q, Yan X-y, Xing G-x, Zhu Z-I (2009) Nitrogen fate and environmental consequence in paddy soil under rice-wheat rotation in the Taihu lake region, China Plant and Soil 319:225-234 doi:10.1007/s11104-008-9865-0

Zhao Z et al. (2020) Modeling CH4 and N2O emission patterns and mitigation potential from paddy fields in Shanghai, China with the DNDC model Agricultural Systems 178 doi:10.1016/j.agsy.2019.102743

Zhou M, Wang X, Wang Y, Zhu B (2018) A three-year experiment of annual methane and nitrous oxide emissions from the subtropical permanently flooded rice paddy fields of China: Emission factor, temperature sensitivity and fertilizer nitrogen effect Agricultural and Forest Meteorology 250-251

\section{Figures}




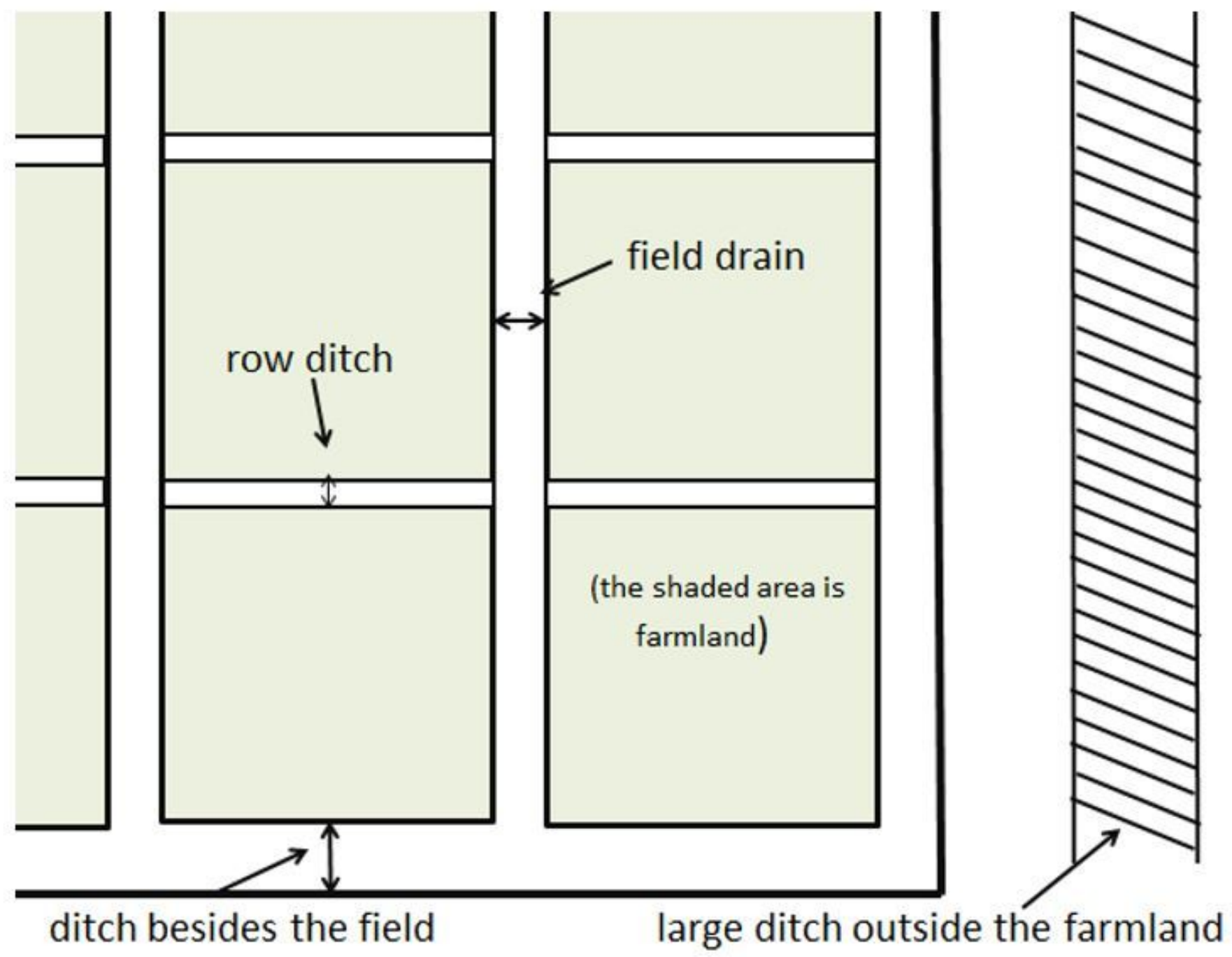

Figure 1

Schematic diagram of the field ditches. 


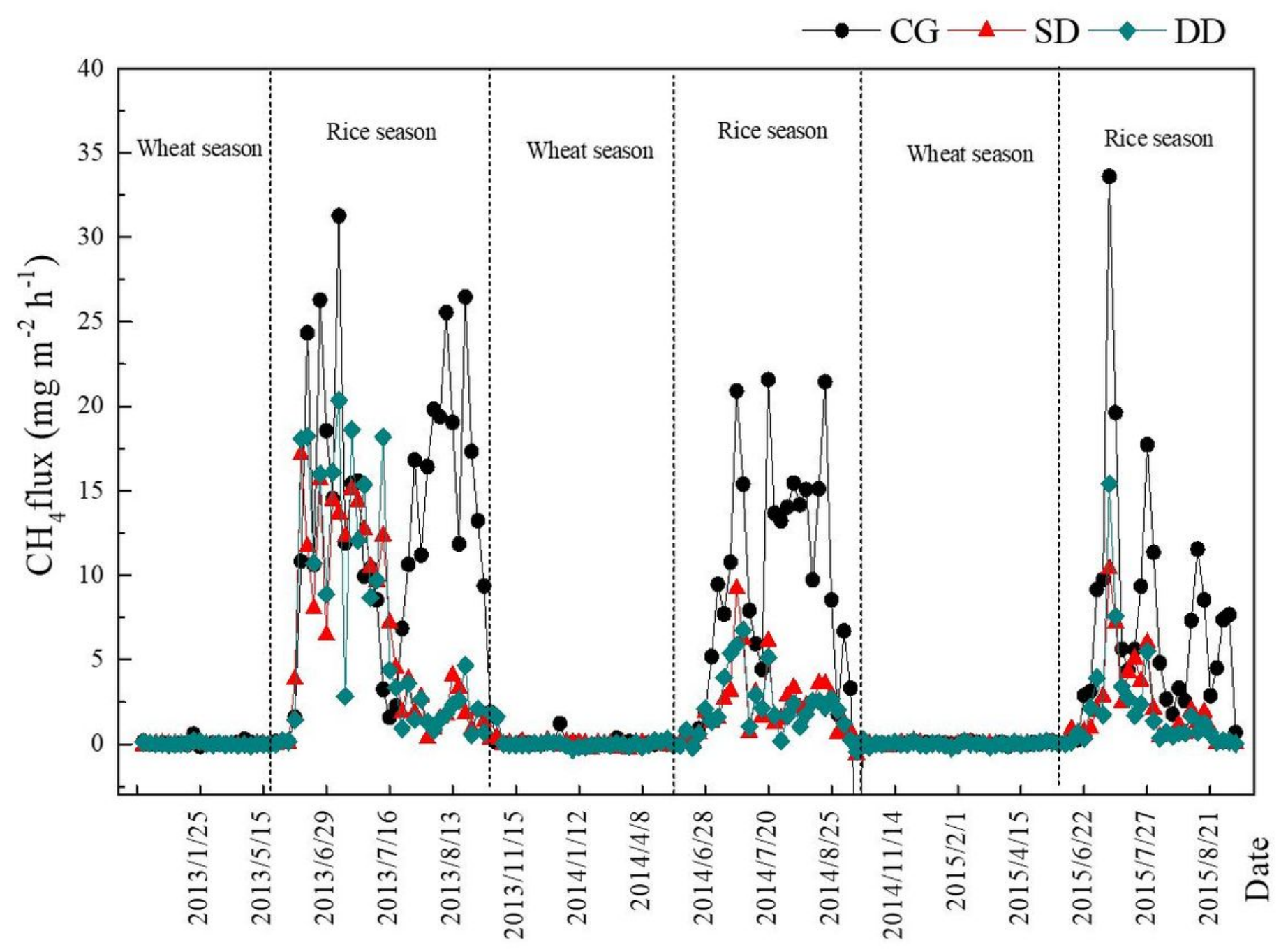

Figure 2

$\mathrm{CH}_{4}$ emissions in each treatment in the rice-wheat seasons in the three years. CG, SD, and DD CG, SD, and DD represent the treatment of ditches of different depths for drainage during the wheat season, CG: control group; SD: shallow ditch; DD: deep ditch. The same as below. 


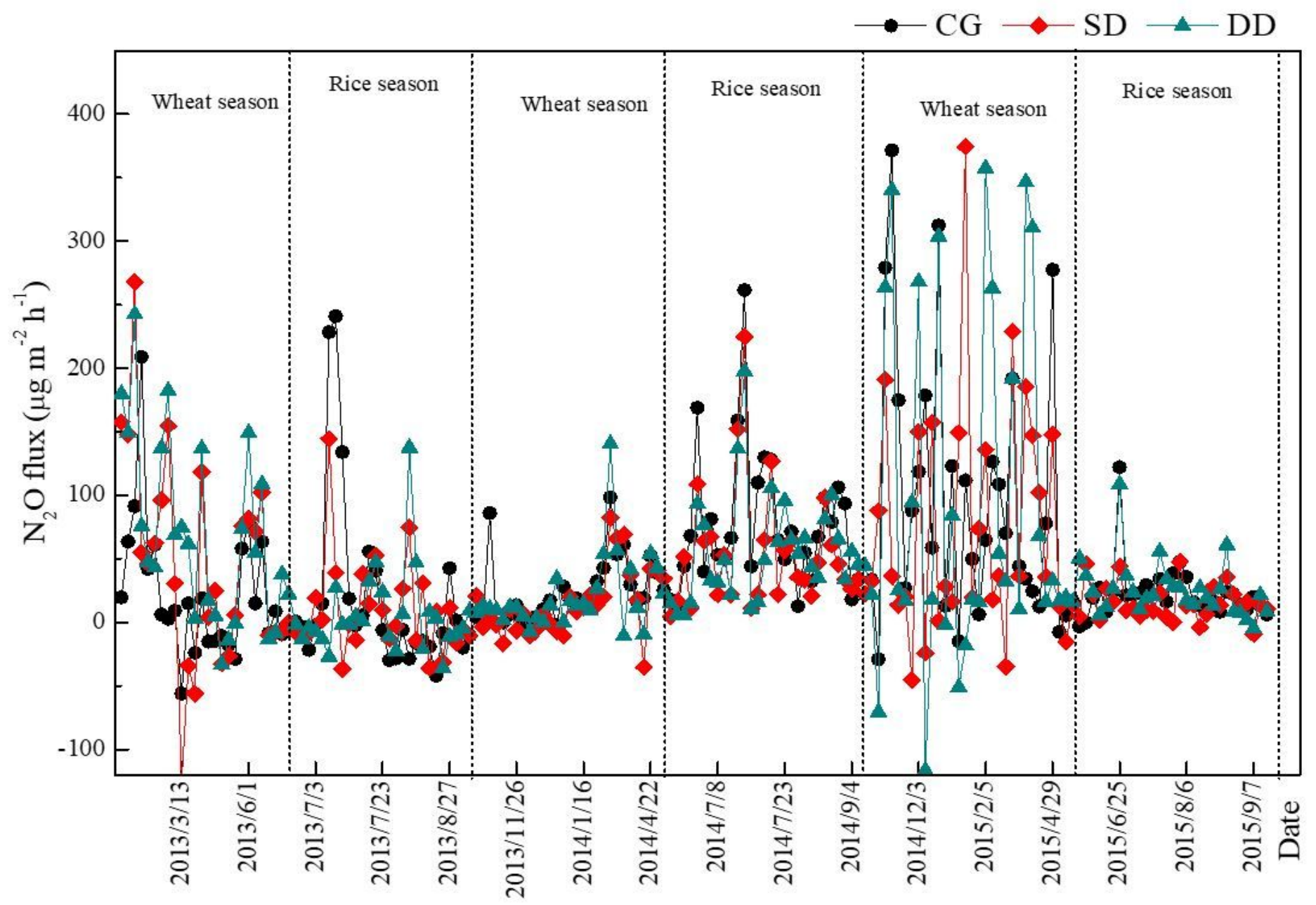

Figure 3

Seasonal variation of $\mathrm{N}_{2} \mathrm{O}$ emission flux during the rice growth period in the three years. 


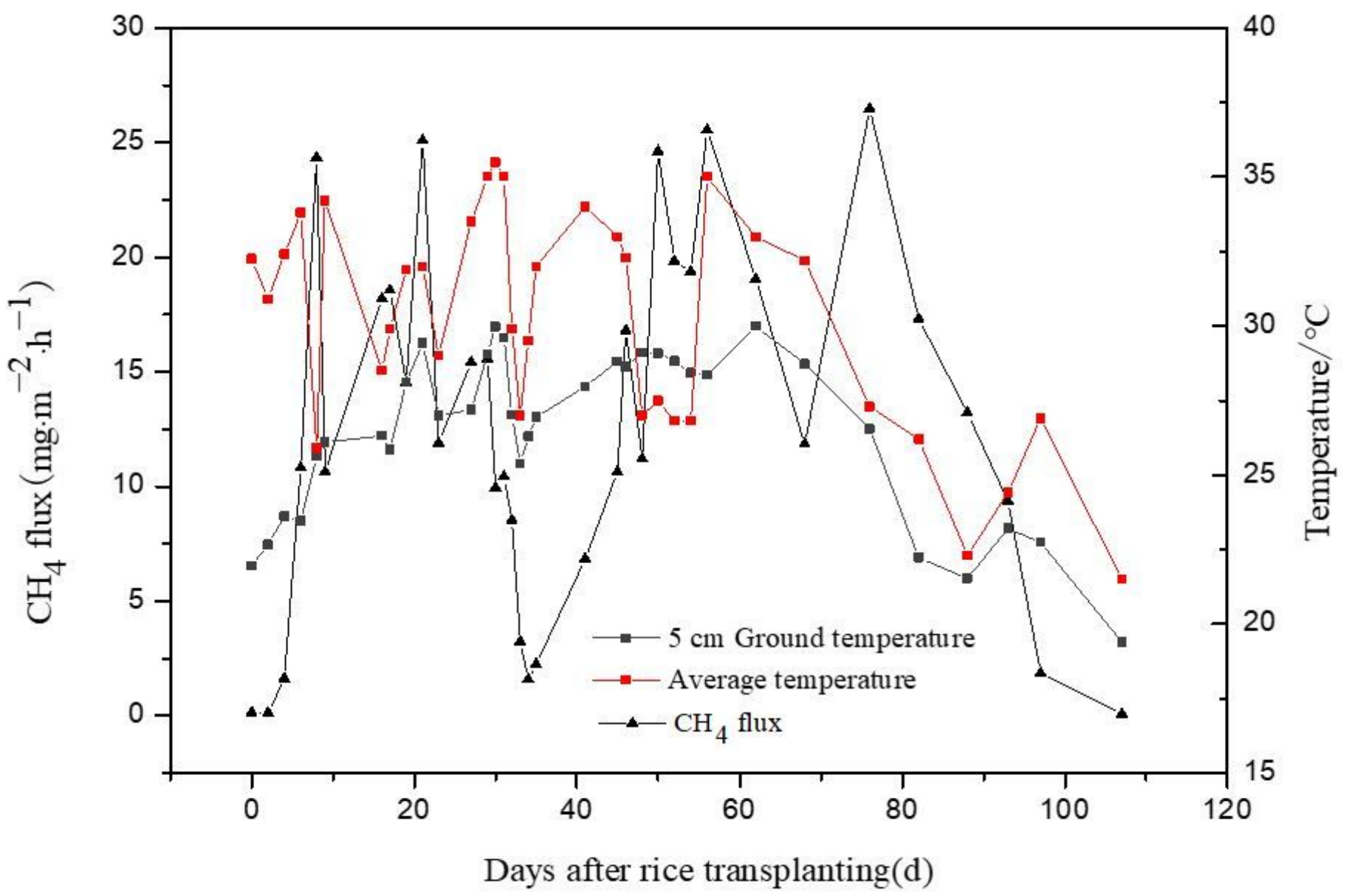

Figure 4

Relationship of the atmospheric temperature, $5 \mathrm{~cm}$ ground temperature, and seasonal variation of $\mathrm{CH}_{4}$ emissions in the rice season. 

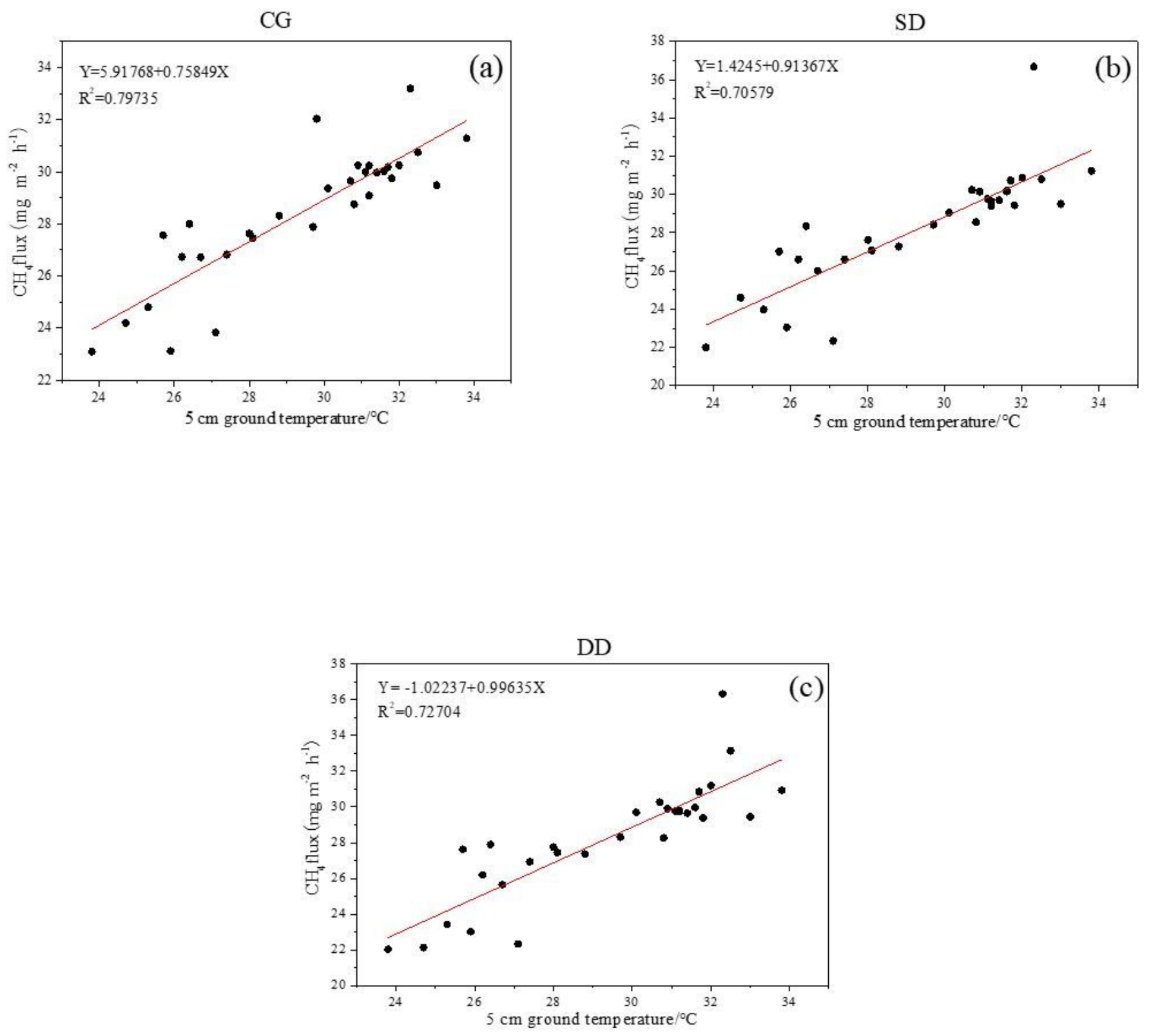

Figure 5

Relationship between the $\mathrm{CH}_{4}$ emission flux and $5 \mathrm{~cm}$ ground temperature in each treatment. 

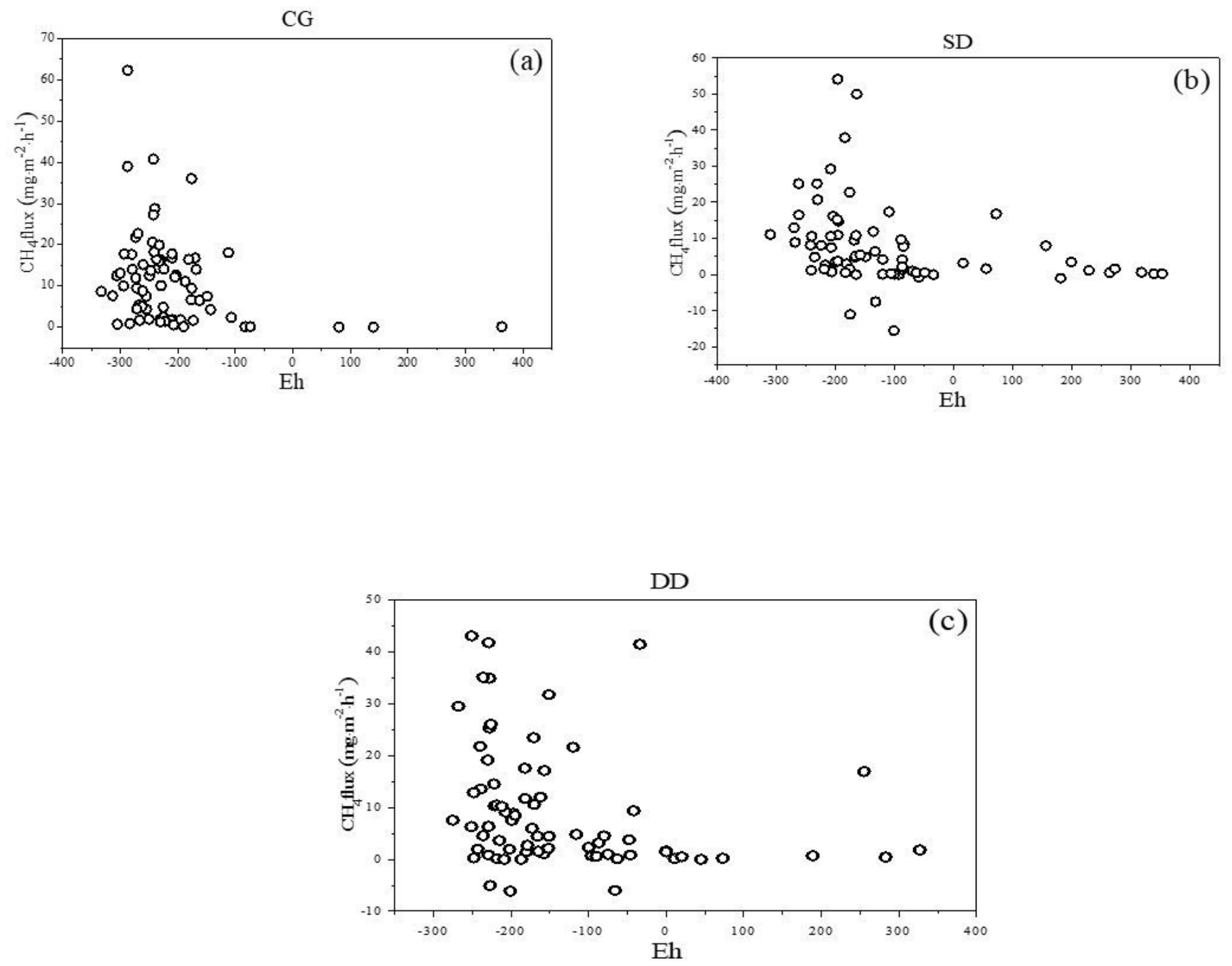

Figure 6

Relationship between the Eh value and $\mathrm{CH}_{4}$ emission flux in each treatment $(\mathrm{a}, \mathrm{b} \& \mathrm{c})$ 

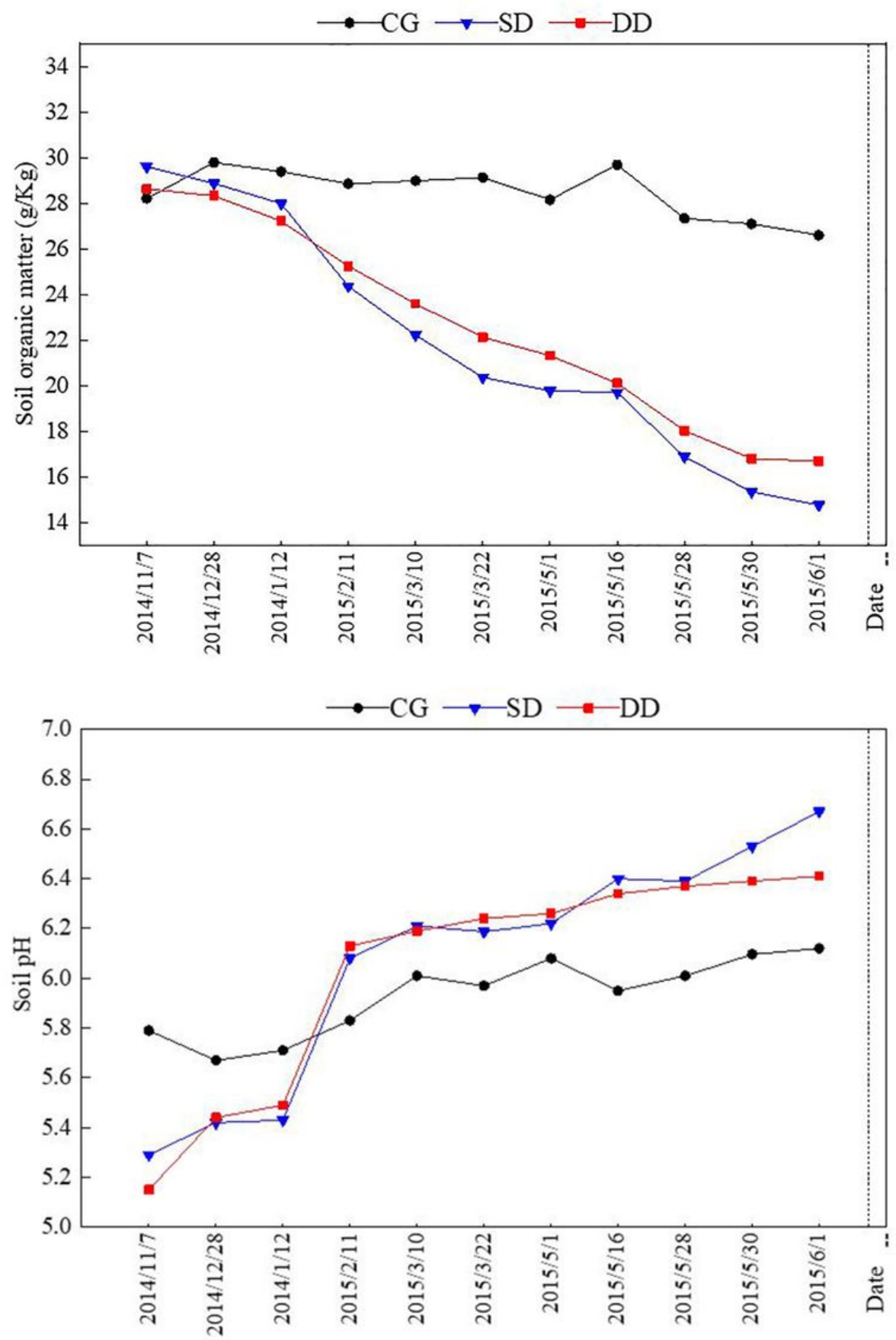

Figure 7

Changes of soil organic matter and soil pH in the wheat season in 2014-2015 